\title{
To Die For: The Semiotic Seductive Power of the Tanned Body
}

\author{
Phillip Vannini \\ University of Victoria
}

Aaron M. McCright

Michigan State University

\begin{abstract}
Human skin burns with prolonged exposure to ultraviolet light. This simple physiological process acquires meaning through social interaction-whereby tanned skin assumes symbolic and semiotic properties. In this article we examine the meanings of tanned skin by focusing on the semiotic seductive power of the tanned body. Drawing from forty qualititative interviews, we examine the motives, beliefs, and experiences of people who tan their skin artificially, that is, through exposure to tanning lamps, in order to understand how tanned skin assumes meaning for them. We analyze the practice of artificial tanning and the interplay among processes of seduction, impression management, self-expression, and the construction, exchange, and interpretation of embodied sign-values.
\end{abstract}

Get undressed-but be slim, good-looking, tanned! —Michel Foucault, Power/Knowledge (1980)

Broadly interpreted, sun worship is an old cultural practice. People throughout history have turned to the sun for a wide variety of activities designed to purify or embellish their souls and bodies (see Douglas 1966). Sun gods from the Greek Apollo to the Egyptian Ra populate world mythologies that place the sun at the center of life. Aesculapian health clinics over two millennia ago attempted to cure the ill with sunbathing, and Native American Pawnee dancers of the Bear Society believed the sun gave them healing powers (Randle 1997). A more diffuse and secularized strain of solar worship exists in the contemporary United States. ${ }^{1}$ For instance, municipalities all over the nation attempt to lure prospective businesses and workers to their areas by advertising the total number of sunny days they enjoy each year. People often attempt to cure stress and fatigue by taking vacations in warm, sun-caressed locations and resorts (see Desmond 1999). To most, a "lovely" day has sunny weather,

Direct all correspondence to Phillip Vannini, Department of Sociology, Cornett Building, P.O. Box 3050, University of Victoria, Victoria, BC V8W 3P5, Canada; e-mail: vannini@lycos.com.

Symbolic Interaction, Volume 27, Number 3, pages 309-332, ISSN 0195-6086; online ISSN 1533-8665. (c) 2004 by the Society for the Study of Symbolic Interaction. All rights reserved.

Send requests for permission to reprint to: Rights and Permissions, University of California Press, Journals Division, 2000 Center St., Ste. 303, Berkeley, CA 94704-1223. 
while an "awful" day is filled with rain and clouds. We often seek out companionship with those whom we believe have a "sunny" personality. And a lucky few of us may meet that special person and say, "You are the sunshine of my life."

It is becoming increasingly common for a number of people in our society to actively seek a suntan year-round. While many people tan under the sun, greater numbers each year patronize tanning salons or purchase their own private tanning beds, lamps, and tanning lotions to bronze their skin. In other words, more people are shifting their preference from the real sun to a simulated sun-the tanning lamp. The first tanning salon in the United States opened in 1978, and today the United States has more than fifty thousand salons operating in an industry with twenty-eight million users who generate over $\$ 4$ billion in gross revenues a year (Palmer et al. 2002). With mounting awareness of the risks associated with extensive exposure to carcinogenic ultraviolet (UV) radiation and with the increasing total market value of body enhancement products and services, the practice of artificial tanning has gained enough significance to warrant empirical scrutiny.

In another study (McCright and Vannini 2004), we observed two competing "stories" or frames (Goffman 1974) about artificial suntanning within public discourse: a medical frame and a seduction frame. The competition between these two frames provides the dynamic context in which we may more completely understand why people artificially tan their skin in the contemporary United States. We begin the following section by briefly noting the historical significance of the practice of tanning and artificial tanning and the established medical frame through which many in the public interpret tanning. Since artificial tanning is linked closely to other "projects" of the body such as fitness, fashion, dieting, piercing, and tattooing, we then discuss how the existing literature on the sociology of the body helps to account for this embodied practice. We end this section by identifying the emerging seduction frame and noting the competition between the medical frame and the seduction frame. After discussing our methodology and analytic framework, we report and reflect on in-depth interviews with forty artificial tanners. We conclude by drawing together our observations and offering a brief reflection on the semiotic power (Wiley 1994) of the body.

\section{ARTIFICIAL TANNING IN SOCIOHISTORICAL CONTEXT}

Popular enthusiasm for the sun and suntanning has varied much across both time and space. Eighteenth-century European upper-class ladies, for example, shunned the sun used parasols and cosmetic powder to display pale skin. At that time tanned skin connoted humble class origins, as most unskilled workers and farmers would be tanned from protracted sun exposure during the workday. With the passing of time and with the transition from a production society to one based on conspicuous consumption (Veblen 1899), the meaning of tanned skin changed. As early as the 1920s, tanned skin began to connote upper-class taste and an affluent lifestyle (Holubar and Schmidt 1994). As the popularity of leisurely outdoor pursuits such as lawn 
tennis, swimming, golf, and sunbathing brought the bodies of the wealthy outside to play, the pale body began to signify confinement to indoor workplaces and lack of discretionary income. The shift from the symbolic to the semiotic realm had begun to emerge: bronzed skin was no longer merely indexical of exposure to UV rays; it connoted sign-value. ${ }^{2}$

Enticed by Coco Channel's famous pronouncement, "The 1929 girl must be tanned. A golden tan is the index of chic!" America's love affair with suntanning officially began in the 1930s. With the popularization of the bikini swimsuit in the late 1940s and 1950s and the romanticization of the southern California lifestyle, it was not long before Hollywood stars and fashion models began to show off their bronzed bodies and rave about their tans (Randle 1997). Whereas the first advertisement for a tanning lamp appeared as early as 1923 in Vogue magazine (Randle 1997), the artificial tanning business only began to gather meaningful popularity in the 1980s in North America and western Europe. The widespread emergence of tanning salons and the rise of retail sales of tanning lamps coincided with the invention and distribution of more technologically advanced lamps capable of delivering UV light five times as intense as that of normal sunlight (National Institute of Health 1989). According to the Indoor Tanning Association (2004), the professional indoor tanning industry now employs more than 160,000 employees and has a total annual economic impact in excess of $\$ 5$ billion.

\section{The Medical Frame}

Over the past two decades a critical mass of physicians and health professionals, medical associations (e.g., American Medical Association, American Association of Dermatology), medical organizations (e.g., American Cancer Society, Skin Cancer Foundation), and federal agencies (e.g., National Cancer Institute, Federal Trade Commission, Food and Drug Administration, Centers for Disease Control and Prevention) have begun to pay attention to the phenomenon of tanning, artificial tanning in particular. This collective is responsible for promoting a major frame through which many in the general public interpret artificial tanning (McCright and Vannini 2004). Medical frame proponents claim that decades of peer-reviewed research finds that prolonged exposure to solar UVA and UVB radiation and occasional sunburns are risk factors for all three types of skin cancer: basal cell carcinoma, squamous cell carcinoma, and melanoma. These proponents further claim that artificial tanning devices also expose people to UVA and UVB radiation, and the preponderance of existing peer-reviewed empirical research finds that use of artificial tanning devices also increases the likelihood of contracting skin cancer (see, e.g., International Agency for Research on Cancer 1992; Swerdlow and Weinstock 1998; Westerdahl et al. 2000). ${ }^{3}$ They argue that this heightened risk is present across the population of artificial tanners, from male adults to female teenagers, and is especially acute for people with fair skin, light hair color, and blue or green eyes 
(see, e.g., Demko, Borawski, and Debanne 2003; Randle 1997; Swerdlow and Weinstock 1998).

Thus, medical frame proponents claim that artificial tanning is an extremely risky behavior. At the very least, they argue, the indoor tanning industry must be regulated so that a company can proclaim that its products produce a "safe" tan with "no harmful rays" and "no harmful or adverse effects." At the most, individuals should refrain from using the products and services of the indoor tanning industry to protect themselves from unnecessary exposure to known carcinogens (and thus an increased risk of skin cancer). The American Academy of Dermatology has publicly discouraged the practice of artificial tanning, and the American Medical Association also has requested a ban on the sale of artificial tanning equipment (AMA 1994). We now turn to the sociology of the body literature before identifying a key competitor with the medical frame-the seduction frame.

\section{Sociology of the Body}

The sudden emergence and consequent rapid growth of what has come to be known as the sociology of the body (see, e.g., Falk 1994; Featherstone 1991a, 1991b; Featherstone, Hepworth, and Turner 1991; Frank 1991; Richardson and Shaw 1998; Shilling 1993; Turner 1991, 1996) prompted one symbolic interactionist (Strauss 1993) to remind us that it was George Herbert Mead who first advanced much of what we now consider novel theorizing about this topic. We largely concur with Anselm Strauss that Mead's (1934) pragmatist philosophy contained the genes of our contemporary nondualistic thinking about the body. There is no body without an agentic, reflexive, and semiotic self (Wiley 1994), and interaction is first and foremost an interaction of signifying bodies. Through our bodies we perform, express, and (re)present ourselves, and others judge our appearances and performances. The body is both a subject and an object of action, and it is through our self-directed action and reflection that we communicate with others (Mead 1934; Peirce 1960; Strauss 1993). ${ }^{4}$

We understand artificial tanning as a body practice that "serve[s] to enhance, promote, denigrate, destroy, maintain or alter performances, appearances, or presentations" (Strauss 1993:121). In addition, we see tanning as a form of communication occurring through the body and entailing "cooperative activity with others and [being] the basis of shared significant symbols (Mead 1934), giving meaning to what one feels, sees, hears, smells, and touches" (Corbin and Strauss 1988:54). The tanned body derives its meanings from its position as both a subject (through its relation with a self and others) and an object (to the self and to others). Following Strauss, we can therefore say that there is "action on the [tanned] body, toward the [tanned] body, or with respect to the [tanned] body" (Strauss 1993:120; emphasis in original), and consequently performances by the tanned body and appearances of the tanned body. The symbolic and semiotic properties of such bodily performances and appearances stand in a reflexive relation to a semiotic self that evaluates meanings 
associated with the past untanned "Me" and, through a present agentic "I," acts toward an ideal future tanned "You" (Wiley 1994).

Gregory Stone (1962) and Erving Goffman (1959) identified the importance of managing bodily appearance and impressions through careful manipulation of the semiotic power of objects such as clothing, props, and settings. More recently, symbolic interactionist studies on the body have highlighted the meanings of performances and practices as varied as tattooing (Sanders 1989; Vail 1999) and exhibitionism in sexually charged Internet-mediated communication (Waskul 2002). These studies document the contemporary social trend toward a presentation of the self that takes place through actual or virtual, permanent or temporary modification of the body or body parts. Barry Glassner $(1988,1989)$ also noticed this trend and advanced the argument that the seductive power of images typical of postmodern culture has resulted in the boom of fitness programs and facilities, in the expansion of dieting clinics and programs, and ultimately in the widespread acceptance of plastic surgery. In essence ours is an image-centered culture based more than ever before on the power and widespread acceptance of seduction ${ }^{5}$ as a form of strategic interaction (Baudrillard 1990a, 1993). In the contemporary United States, tanned white skin may connote that its possessor is a healthy, relatively affluent, sociable, physically fit, and attractive person, for example, and because the value of this object empowers, enhances, or endows the appearance of an enselfed body, we can say that tanned skin has not only a symbolic meaning but also semiotic power.

\section{The Seduction Frame}

Consistent with Glassner's $(1988,1989)$ argument on fitness and selfhood, we have documented the emergence of a seduction frame through which many in the general public interpret artificial tanning (McCright and Vannini 2004). This seduction frame is promoted explicitly by individuals (e.g., tanning salon owners and employees) and organizations (e.g., Indoor Tanning Association, National Tanning Training Institute, International Smart Tan Network) in the indoor tanning industry and implicitly by much of popular culture (e.g., beauty professionals, celebrities, and popular magazines). ${ }^{6}$ Seduction frame proponents claim that regular bronzing of the skin will increase a person's physical attractiveness and overall mental and physical health. They claim that a suntan will heighten your physical beauty, help you look more athletically fit, and improve your self-esteem and self-confidence. In addition, they argue that sunlight may help people live longer, healthier lives since sunlight provides vitamin $\mathrm{D}$, affects more than a hundred bodily functions, and is believed to increase longevity. Contrary to most existing scientific evidence, seduction frame proponents claim that sun exposure and tanning does not cause skin cancer. Indeed, these groups argue that suntanning dramatically reduces the risks of many other types of cancer. Ultimately, seduction frame proponents claim that artificial tanning is smart or good, because it is the most rational (i.e., efficient, standardized, and controlled) way to reap these seductive benefits. 
The seduction frame encompasses some of the most common characteristics associated with postmodern society, such as the culture of the seductive image (Baudrillard 1993; Glassner 1988, 1989) and expressive personal appearance (Featherstone 1991a, 1991b). It connects the tanned body's appeal to a political economy of bodies and consumer objects and its meanings assume sign-value and symbolicexchange value (see Baudrillard 1968). By tanning, the self plays with the authenticity of its body. The body technology of artificial tanning seemingly serves to liberate the white self of its pale appearance and enables the tanned white self to achieve a mythical seductive authenticity. In the seduction frame, then, the tanned self achieves its semiotic seductive power through its appeal for a voyeuristic crowd of both intimates and strangers. Consequently, the tanned self derives its self-esteem through the narcissistic realization of its semiotic power.

The triadic relation between the self, the body, and society is a semiotic one (Wiley 1994). However, the meanings that this semiotic relation may assume are largely dependent on the various frames through which people interpret how the tanned self is performed. We have identified the core elements of two competing frames. The medical frame highlights long-term costs and avoided risks and embodies coercive/repressive discursive power (e.g., "No, you shall not!"). On the other hand, the seduction frame highlights largely short-term costs and desired risks and embodies productive power (e.g. "Yes, you shall!"). While the essence of these frames is relatively stable, we argue that they nonetheless result from ongoing, contested processes that are similar to the dynamics of social movement framing processes (Benford and Snow 2000). The medical frame competes with the seduction frame for the definition of tanning practices. Tanners differentially internalize the essence of these two competing frames, and this evolving competition continues to influence their perceptions and negotiations of tanning practices.

\section{METHODS AND DATA}

The data we analyze in this research consist of forty qualitative interviews with artificial tanners. The interviews were semistructured and nonstandardized (Denzin 1989). The length of interviews varied between thirty and sixty minutes. We occasionally interviewed more than one individual at a time when friends said they would not mind talking to us together. We gave each participant the option to terminate the interview at any point and the freedom to refuse to answer any question. We granted confidentiality to everyone who agreed to participate, and we report only pseudonyms below.

We contacted tanners through snowball sampling. We initially asked for volunteers in several large upper-level sociology classes at one midsized public university in the Pacific Northwest to put us in touch with friends or family members who artificially tanned and who would not mind speaking to us. Later we managed to contact five more male tanners in a different city in the Pacific Northwest. In addition we contacted a tanning salon manager and another tanning salon worker, both 
of whom introduced us to artificial tanners of various ages and backgrounds. Our sample consisted of twenty-three women and seventeen men. The ages of tanners ranged from eighteen to fifty-two, but most were between twenty and thirty years old. All were of white European background, except for two men who were Japanese. We collected basic background information about each participant, such as age, place of birth, places of recent residence, and ethnic and class background. There was some socioeconomic diversity among tanners, but all had what could be considered a middle-class background. Finally, we taped, transcribed, and coded interviews for similarity and variability among themes (Denzin 1989).

We approached interviews from the angle of social semiotics; that is, besides asking artificial tanners about their own practices, we asked them to interpret the meanings of tanning. In doing so, we intended to learn how tanners give meaning to tanned bodies. For example, we asked artificial tanners questions such as "What does a tanned body communicate about a person?" and "What does a pale body communicate about a person?" Peter Manning (1987) suggested that researchers can combine semiotics and fieldwork and that the results can maximize the interpretive value of research. We derive inspiration from Manning's work by asking ourselves how our research subjects are "oriented to the messages" (Manning 1987: 43) they communicate to others through their bodies and through what frames they exchange these messages. Precisely, we asked our research subjects what they intended to communicate about themselves through their tanned bodies and what information they could learn about others by simply looking at their tanned bodies. However, we also deviate from Manning's conceptualization, as we rely on Peircean rather than Saussurean semiotics.

Norman Denzin (1992) suggested that symbolic interactionism must develop a more refined approach to the theoretical and empirical study of signs and sign systems and must link that semiotic approach to the critical study of the operation of ideological systems. Social semiotics provides researchers with such a framework (Gottdiener 1985, 1995; Hodge and Kress 1988; Vannini 2004). Social semiotics is based on pragmatism and American semiotics (e.g., Peirce 1960)_-as well as on critical linguistics (Halliday 1978) —and opposes formalism, idealism, and European structural semiology (e.g., Saussure 1959). There is a sharp difference between social semiotics and semiotics. Social semioticians follow both Peircean pragmatism and a critical epistemology and believe that meaning arises out of social interaction. Semioticians instead are formalists and idealists and believe that meaning arises out of the structure of signs and sign systems. In short, social semioticians share much with symbolic interactionists (Vannini 2004), as they also believe that power plays a crucial role in the process of assigning meaning to signs, which is known as semiosis. Because semiosis always takes place in a context (known as an exosemiotic context) bounded by specific historical, political, economic, and cultural relations, the construction, exchange, and interpretation of signs are shaped by heterogeneous relations of power. Therefore, when interpreting tanners' own interpretations, we paid close attention to the positioning of meanings within discursive frames and within the power configurations that characterize these frames. 


\title{
TALKING WITH ARTIFICIAL TANNERS
}

\author{
Becoming an Artifical Tanner
}

Medical studies have found that people begin artificially tanning at young ages and continue to tan with highly variable frequency (Cokkinides et al. 2002; Demko, Borawski, and Debanne 2003; Geller, Colditz, and Oliveria 2002; Knight, Kirincich, and Farmer 2002; Mawn and Fleischer 1993; Young and Walker 1998). The women in our sample began tanning earlier than did the men. In general, younger (i.e., ages twenty to thirty) women started artificially tanning during their first few years of high school, whereas younger men began tanning as late as the senior year in high school or even later, during their early twenties. The older women in our sample (i.e., over thirty) started tanning in their thirties and forties, which approximately coincided with the late 1980s and early 1990s. None of our informants began frequenting tanning salons before the late 1980s. The earliest a participant began tanning was at age twelve; accompanied by her mother in preparation for a family trip, she later quit tanning and did not begin again until her late teens.

As technologies became widely available with the rise of consumer demand in the 1980s, tanning salons relied on a rapidly expanding body-consumer culture to increase business volume. Following Featherstone (1991a), we suggest that the practice of artificial tanning has coupled the traditional concept of self-preservation of the body with a newer vision of the body as a sign of youth, pleasure, and self-expression. This trend partially resulted in the commodification of the body, which works in different ways across different age groups. For older consumers, a tanned skin may be desirable because it helps to conceal age spots and skin blotches and also makes it difficult to perceive skin wrinkles - thus providing an illusion that it halts the aging process. However, the obvious biochemical fact is that extensive tanning actually accelerates the aging of the skin (but visible signs of this are evident only in the long term, long after the short-term benefits of tanning cease). Younger consumers who may not yet be interested in slowing the signs of aging interpret tanning differently as it helps to highlight muscular tone, thus making one's silhouette seem thinner. Physical appeal and self-expression play an important role in the development of adolescents' identities, and in light of the sharp increase in teenage buying power it is not surprising that they constitute a large segment of the tanning market (see Danesi 2003).

We investigated the interplay of motives and age by inquiring about the first tanning salon experience. In their narratives, interviewees emphasized the uncomfortable feeling they associated with lying on a coffinlike bed. For example, Kristi reported:

The first time was freaky; God, I can still remember how freaked out I was. To begin with, you walk into this tiny room where there is little or no furniture except for the bed. And it stinks in there, I mean ...Ew! It literally smells like burned up flesh. You know, they have fans, and I guess they try and clean it all up before a customer walks in, but it still smells like they have literally been burning up bodies in there. And if you get past that like I kind of did, you lie on the 
glass bed and you know how you have to close yourself in, right? Well it felt like I was dead and that was my coffin. It was hot in there, I began getting really sweaty and impatient, and when I got up my skin was all icky. It felt really weird.

The sense of sacrifice documented above points to the asceticism present in tanning. Within the seduction frame, beauty, fitness, and health are not perceived as natural properties but rather as the fruit of hard work. Interestingly, this self-discipline goes hand in hand with the hedonism and narcissism underlying the contemporary concern with body appearance enhancement (Featherstone 1991a). The preoccupation with the seductive body generally reflects a new ethic that calls for every body to be aesthetically pleasing and relatively healthy and condemns the unfit, the smoker, and now the pale as the new deviants (see Edgley and Brissett 1990).

Women tanned more frequently than did men, although frequencies varied greatly. One needs both time and money to use a tanning salon, and these resources vary across individuals and time. Moreover, people often buy tanning salon packages that end up structuring their attendance. For example, some tanning salons sell monthly passes for unlimited tanning, whereas others sell session-based packages that can include from as few as five sessions to as many as twenty. ${ }^{7}$ Some salons also sell yearly passes and often use incentives to lure patrons to return. For example, a salon may use a point system that allows a patron to tan more cheaply as he or she tans more frequently throughout the year. In spite of these incentives, most tanners' schedules are inconsistent. A typical tanner, for instance, may go to a salon as often as three or four times a week during a "peak" period and then discontinue tanning for as long as two months. Tanners must decide on the costs and benefits of different types of investment. Some of the students we interviewed admitted tanning less at times during the semester when studying is a priority. Older tanners, such as some parents we interviewed, told us that they could not afford to go to tanning salons when large and important family expenses took precedence. Clearly, tanning is a form of investment in one's physical capital that must be understood within larger socioeconomic dynamics.

Habitual, or "heavy," tanners (sometimes referred to as "tanorexics" or "tanaholics") are a minority, but it is difficult to estimate the size of this group. In fact, whereas we spoke to only three young women who admitted tanning as often as two or three times a week approximately every week, there may be a discrepancy between admissions and the truth. In our interviews with salon workers we discovered a different reality, as the following excerpt from Laura's comments testifies.

You know, I have to tell you that at my salon we had two conflicting priorities, I guess you could say. On one hand, we're in business to make money, but on the other hand, we know that some people are just getting sicker and sicker as a result of coming in. We give people disclaimers, we warn them about not coming in too often, and whenever we found it necessary we can simply not let someone in because they look just too tanned. When I was working [at the salon] I had a pretty good number of ladies, some quite older than the average girl who comes in, who would try and come in every day, and I mean every day. And I don't 
know how many times I saw them try to come in more than once a day. If I happened to be working the second time they'd show up I'd send them home, but I know that they would come in later on when I was off and tell a coworker of mine that that was their first of the day. And if that didn't work out they would go over across the street to one of the other salons in the area.

Every commodity and service produced in a capitalistic society has the potential of being addictive because of its seemingly endless supply. Consumer products and services have seductive qualities, but as Baudrillard (1990b:73) explained, "the age of hidden persuasion is over." Instead, seducers openly display their symbolic-exchange value (Baudrillard 1990b:73). Tanners, for example, uncover their bodies and display their bronzed skin for everyone to see: hiding tanned skin would be senseless. Furthermore, the body lies at the center of all addictions because the logic of endless consumption may serve to push away, at least illusorily, death (Baudrillard 1993). While none of the people we interviewed admitted to having an addiction problem, almost all of them told us they had friends or acquaintances who may be tanaholics. For example, twenty-year-old Janet told us that she recently had an animated argument with her roommate who, according to Janet, needed help to stop her incessant tanning.

Everyone with whom we spoke identified certain peak tanning times that largely coincided with the following seasons: the arrival of spring, the arrival of summer, and the weeks before the winter holiday season. The arrival of spring and summer motivated our artificial tanners in similar ways. In warm weather, individuals spend more time outdoors and wear more skin-revealing clothing:

Justine: You know how it is, I mean for us girls, we normally wear less in the summer or spring than in winter, and it just looks bad if you're as white as snow in the middle of June or July.

Bryan: Well, when summer comes around you want to look a little nicer and wear shirts or stuff like that. I like to work out and lift weights, and sometimes I can do that outside in our house's backyard. But sometimes I'll end up just working out at the gym, so you can't really get tanned unless you go to a salon. Besides, if you go to a salon you get to even your tan up. It sucks when you have tan lines.

Of course, these seasonal occasions have strong social implications for the presentation of the embodied self. Goffman $(1959,1963,1967,1969)$ taught us that agency plays a central role in bodily performance. By controlling and monitoring their bodies in order to maximize the benefits of social interaction, tanners make strategic use of the semiotic power of their skin. Performing the embodied self at a wedding, a prom, or any social event requires that one look one's best at a time when the norms contained in the "shared vocabularies of body idiom" (Goffman 1963:35) are most intense and demanding.

One would assume that when it is sunny and warm outside tanners would prefer sunbathing to tanning salons, but this is not always the case. The arrival of the warmer months (which in the Pacific Northwest occurs usually around mid-April) 
requires that skin be ready for the upcoming hot summer days. For many artificial tanners, the spring season and very early summer are times of intense salon attendance. When summer weather brings continuous sunny days, then the need to artificially tan slightly decreases, but it does not disappear. At this time, many artificial tanners will frequent salons in combination with sunbathing, so that artificial tanning prepares one to sunbathe when sunbathing is possible and also enables one to tan when it is not. As stated above, a few individuals in our sample tan year-round, and even those who do not, feel there are a number of benefits in tanning during the cold months of the year. For example, those who tan around Christmastime do so to prepare for holiday trips, family reunions, or various social occasions (such as New Year's Eve parties). Furthermore, the few who tan more during autumn and winter do so because they enjoy the feeling of warmth associated with tanning on otherwise cold, bleak days or simply because they just want their skin bronzed at all times.

We asked our informants if they would consider stopping tanning at some future date. A few, mostly women, admitted they would not quit in the foreseeable future. Others told us they had neither thought about it nor believed they might quit when time or money becomes scarce or when their priorities change. Megan, quoted below, is a young woman whose skin was oddly orange-colored and marked with spots and moles.

Megan: Yeah, I guess ... I could stop one day. I know that it's not good for you. I mean my mom got skin cancer because of it. . .

Interviewer: You mean your mother right now has skin cancer because of tanning too much?

Megan: Oh yeah, and she lives in Hawaii, and so she tans outside a lot too, and the doctor told her it's basically because of tanning too much. Anyways, I know that I don't have it yet, so I guess I can always stop when I start to see moles popping up on my skin.

As we discuss in depth below, perceptions and behaviors such as these are enabled or motivated by the alluring power of the interpretive frame that individuals use to assign meaning to signs. While psychology can explain individual risk-taking behavior, the social conception of risk and the culture-dependent evaluation of costs and opportunities associated with choices and action outcomes lie in the semiotic power of the interpretive frame that artificial tanners use. In simple words, Megan, whose disposition may be shocking to us, is simply choosing the seduction frame because it is more appealing to her than the medical frame.

\section{Motives}

We found one underlying motive for artificial tanning: the enhancement of one's appearance. Informants clearly linked body image with self-esteem. With no exceptions, our informants told us that tanned skin improves their looks in different ways (see Netburn 2002). For example: 
Kate: It's better brown and fat than white and fat!

Amber: It makes me look thinner, I mean, I'm sure a lot of women have told you that it makes them look like ten pounds less.

Immanuel: Well, I actually used to have acne when I was younger and obviously I hated that. I heard that tanning would clear up my skin, so I started doing it and I kept on doing it and I like myself better now.

Ted: It's kind of cool cuz it helps you bring out your definition. ... It just saves you so much work at the gym cuz it really makes you look more shaped and lean, you know.

As we discovered, informants believe that tanning improves their appearance in many ways. Some tanners like to wear gold jewelry or bright-colored clothing, and tanned skin enhances the contrasts. Others like to be outside in the spring and summer, and tanned skin makes them feel more comfortable at the pool, on the beach, or anywhere where other people may be tanned. Some women find themselves dating after a failed marriage and believe that tanning-together with dieting and cosmetics-gives them an edge in the dating scene. No matter what the specific strategy is, tanners' ultimate goal is to manage the impression they make by looking more seductive to others and themselves. The semiotic principle on which this conduct is based is rather simple: an object (tanned skin) connotes positive characteristics such as youthfulness, sexiness, sociability, affluence, and healthfulness. Tanners then use these meanings of bronzed skin in a variety of ways beneficial to them. The most evident of these ways is the use of tanned skin in strategic (seductive) interaction (see Goffman 1969).

Possibly the most common purpose of artificial tanning is to obtain a "base tan," which helps one to prepare for more tanning.

Krissi: What I do a lot of, is go to a salon to get a base. Like, when spring comes around and I have a plan to go on a trip, like last year for example. Before I went to Hawaii I bought a package of ten tans at a salon to get a base before going to Hawaii, so that I could get there and tan outside and not get burned ...

Interviewer: So you didn't get burned?

Krissi: Yeah I did actually. I got burned here and in Hawaii [laughs]. But that's because I tanned too fast, I mean before leaving, and when I got to Hawaii it was so nice that I spent too much time outside [laughs].

Managers of artificial tanning salons know that many patrons come in to get ready for suntanning immediately before times of the year when road trips are common. The salon workers we interviewed told us that salons will often offer considerable discounts around spring break and before long weekends such as President's Day or Memorial Day. Tanners believe that by "getting their skin ready" for a major suntan they will avoid burns - an idea they find appealing. Not only are burns painful, but being burned during a holiday trip may cause them to look unsightly (and even incompetent) and thus stay away from the pool or the beach where the action is. While this interpretation seems guided by the seduction frame, it also illustrates the apparent influence of the medical frame. ${ }^{8}$ 
When asked if they preferred results obtained through artificial tanning to those obtained through sunbathing, most of our informants chose the former. Some suggested that a "real" suntan looks more natural-but only insofar as it is uniform, and many admit that a uniform suntan is very difficult to achieve. Others claimed that an artificial tan is more even, is easier to control by going to a salon regularly, and is safer. In addition to appearance enhancement, artificial tanning offers a relatively wide variety of advantages especially in comparison to natural sunbathing. Informants, both male and female, agreed on the following about sunbathing: it takes too much time; it is boring laying outside just to get a good tan; it demands privacy; it requires adequate space, which may not always be available; it is much too dependent on the presence of good weather; and it often causes tan lines (while on a private tanning bed one can freely tan in the nude).

In sum, the simulation (tanning lamp) becomes more efficient than the real (sun) (see Baudrillard 1983), and artificial tanning guarantees quick and efficient results, privacy, and predictability. The only problem for almost everyone is the somewhat mythical orange boundary line:

Justine: I don't think there's that big of a difference between a real tan and a fake bake [artificial tan]. I mean, like I said, I think fake-baking is more convenient, but then you gotta be real careful about it. I'm sure you've seen these girls at the gym who just look like oranges. Seriously, don't they have any friends to tell them it looks stupid? That's where you gotta draw the line, when it looks fake...

Interviewer: But wait, it is fake!

Justine: Yeah, but the problem is when it looks fake.

Justine's declaration is quite interesting when examined from a symbolic interactionist and dramaturgical perspective. As Goffman (1959) explained, there is a clear difference between impressions we give and the impressions we give off. While an audience and a performer tacitly agree that the performer is strategically managing a certain front, they are also participating in an information game in which the performer reveals more information about himself or herself through nonintentional than through intentional communication. The impression given off here is that one is "trying too hard." Health, indeed, is an important component of the seduction frame. When one's skin is too tanned, it serves as a reminder that tanning is also a health risk. This also illustrates the efficacy of the medical frame for the interpretation of tanned skin. With tanning there are socially agreed on conventions about what is and what is not aesthetically pleasing. Through social interaction people create aesthetic norms (Becker 1982) on the fashionableness of shades of tanning much like they create norms on the appropriateness of clothing for specific contexts (Stone 1962). And finally, in relation to the authenticity of a false object (artificially tanned skin), one need only think that it is not the use of technology in itself that invalidates authenticity but rather how technology is used (as in the case of a body that is too tanned) (Grossberg 1992).

An additional concern for artificial tanners who debate whether to rely on the 
sun or the tanning lamp involves which one provides a longer-lasting tan. Most informants believed that a real suntan can stay on longer than a "fake bake," but many were also concerned about getting burned while sunbathing. Thus most salon customers follow a controlled progressive-increment routine under the lamp. They may, for example, start out with a ten-minute session to build up a tan and then move gradually to twenty minutes and then level back to fifteen minutes to maintain it. Salons generally enforce these practices depending on the initial skin tone of a customer. A fairhaired and fair-eyed patron is usually instructed to take it easy on the bed. However, these judgments are left completely to the subjective discretion of those who own their own lamps for home use. One young man who owned such a machine said, "Yeah, I don't care. I'll do forty minutes. Sometimes it feels so nice that I nap in there."

A small minority of interviewees believed they suffered from seasonal affective disorder (SAD) and that exposure to light and warmth during the winter helped them to combat their despondent moods. ${ }^{9}$ Only one informant, however, was diagnosed with SAD by a physician. All of those who mentioned this motive told us that it was only a secondary reason, however.

\section{Of Real Beauty and Symbolic Seduction}

Many artificial tanners with whom we spoke acknowledged that tanning is part of a much larger "package" that includes commercial bodily practices related to health, fitness, and beauty. Katherine, in response to the interviewer's question about how money she spent on her "tanning habit," said:

I put in more than I should, I guess. But you know it's really hard to say. I mean, shouldn't we include the tanning lotions, moisturizers, and accelerants that go with it? I guess it's all part of a package that has to include money spent on makeup, hairdos, paying for the gym, health foods, and more stuff like that.

This is the package about which Featherstone (1991a, 1991b) and Glassner (1988, 1989) wrote. The body plays a central role in our postindustrial economy, and tanning is but another practice that is quickly becoming as common as fitness and exercise. Tanners, then, do not simply get their skin bronzed; they also attempt to make it smooth, toned, young, and healthy-looking. Sex appeal and sexuality play some role in the seduction frame, but it is important to emphasize that a tanned body is also meant to connote ambition, success, and fitness - that is, the ability to fit inthe various contexts of a postmodern society governed by the logic of seductive images (Featherstone 1991a, 1991b).

Because we are interested in the interplay of gender, seduction, and embodied interaction, we decided to explore the extent to which tanners were conscious of their body image. We discovered a number of gender differences. Female tanners seemed to spend much more money than did male tanners, as one might expect from having knowledge of gender expectations of physical attractiveness in our culture. But, more interestingly, some of the men admitted feeling no shame in violating gender expectations. 
Steve: I guess us guys are not supposed to be so much into our own looks, but, whatever, I like myself better when I'm tanned.

Interviewer: Do your buddies give you a hard time?

Steve: Sure they do. They're all like, "Hey dude, did you go tanning yet?" and stuff, but they're just dumb asses, and they say that just to be cool and tough but then they go and do it too. I'd say about half the men in my [fraternity] house tan. I still think that we spend way less money than girls do, though, cuz we don't normally buy all that crap they buy.

Judging from our sample, men who tan understand that there are cultural norms that discourage them from being excessively concerned with their appearance, especially with having a "pretty boy" look. But at the same time, they see tanning as similar to weightlifting, a more traditionally masculine activity. All the men we interviewed worked out more or less regularly and found nothing "effeminate" about tanning. This is an interesting finding because it highlights the link between tanning, health, fitness, and beauty within the common seduction frame. Our interviews with men revealed that tanning has become more normative over time for men. For example, Kazuhiro said:

I lived in London for a while, after I moved out of Japan, and then after that I moved to the States. So I guess I could tell you what it's like to tan in three different countries if you want. But let me tell you that when I moved to the States a few years ago I stopped tanning at first. Here, everybody made a huge deal about tanning, I mean all my guy friends thought tanning was gay and only chicks do that kind of stuff. But then after a while I started working out and hanging out with different people, and I guess that's about the time more men started tanning too, so I started doing it again.

Gender is a performance (Butler 1990), and these young men perform their androgynous identity. This is not an uncommon finding; others have observed how images of masculinity increasingly acknowledge male concern with appearance (Bancroft 1998). A recent pop culture buzzword is metrosexual, which refers to an urban man with refined taste and a strong aesthetic sense who spends substantial time and money on his appearance and lifestyle. We believe that the metrosexual concept, much like the diffusion of tanning among males, is another sign of the pervasiveness of the seduction frame in our culture. To validate this interpretation, we discussed the issue of men who artificially tan with our female informants. Only two women, both of whom are young, told us they thought it was "weird" that men tan. They thought a man should have a more rugged look, not look like a "smooth-skinned pretty boy." None of the other female tanners found it intrinsically strange that men tan, and many explicitly expressed their preference for tanned skin in men-thus underlining the change in gender expectations. Many young women told us that men who tan are also likely to work out, dress nicer, and in general take better care of their appearance and have better taste than-as one female informant put it"men sitting at home on their couch drinking beer and watching football."

All of our interviewees believed that tanned skin is attractive skin, but we wanted to understand how they generated that belief. In other words, aside from 
our knowledge that some people find that tanning is fashionable, we were interested in actual interpersonal exchanges between tanners and their acquaintances. It is through discourse that individuals shape meaning (Blumer 1969), and we were obviously interested in learning about specific instances of interaction. We discovered that tanning is often a topic of conversation among friends (and especially among female friends). Sometimes tanners will drive to a tanning salon together; sometimes they will consult with one another on the best products to purchase, the most effective types of lamps, and the frequency and length of sessions, and so forth. But this "tan talk" also works in other important ways.

Interviewer: So, does anyone actually tell you, "Oh you look nice, you must have been tanning!"

Jessica: Oh yeah, totally. I get it a lot actually, and I can so tell the difference of people's reactions when I'm pale. Just not too long ago I was at my parents' house and my mom saw how pale I was and she told me to get a tan. But that's just one example. My friends, for example, will tell me stuff like "You look nicer when you're tanned" or "Hey I haven't seen you in a while, you look so good tanned like that."

Paula: My kids tan. Both the boys and the girls. And I tell them to.

Interviewer: You tell your kids to get tanned?

Paula: Oh yeah [laughs]. They look so much better when they're tanned.

We discovered that tanners receive positive feedback from different types of people: close friends and acquaintances, family, and romantic partners. Of course, this finding should not shock anyone; we are all aware that we derive our sense of self and our body image from interaction with others (Cooley 1964; Mead 1934). But this feedback loop does not always work in the same way. Most female partners explained that the feedback they receive comes mostly from other females. Justine said:

I usually get that [positive feedback] from my girlfriends. Sometimes my sister may have said something to me, but it's usually friends. Not guys. Guys don't notice that. And if they do, they won't tell you. Guys-that's my theory-they look at the big picture, at the "package," you know what I mean? If a girl has a nice body, she's dressed well, and she looks cute a guy will be like "Oh yeah, she's hot," but I don't know of guys who will focus on a girl's tan and see that apart from the rest. Don't get me wrong, it has to be there though, it's really important. You don't wanna look really really good all around but then be pale, cuz then guys will notice that.

We tested Justine's idea with other female tanners, and they corroborated it. For example, Cassidy told us, "Yeah, I agree with that, totally. And on top of that I'd add that even though we girls may do it to get guys' attention, we also do it to get girls' attention. I mean, not in a sexual way, but there is always that kind of competition among girls, you know.

Evidently, then, what matters to a tanner is the point of view of a reference group of significant others (Shibutani 1961). This obviously varies among individual tanners and is largely dependent on social networking strategies. From the perspective 
of the semiotic self (Wiley 1994), the tanner's self poses a future "You" as an ideal self and uses past "Me's" as references for present action. This semiotic and reflexive self then uses the technology of artificial tanning to reach an ideal state of tanned authenticity.

Everyone in our sample thought that tanned skin connotes health and that a pale complexion signifies illness and poor health. This is clearly ironic as recent medical evidence points out that tanned skin is indexical of rapid aging and possibly even cancer. But medical discourse is not very convincing or compelling among tanners. We asked our informants to reflect on this issue. Katja's insightful statement raises a central point of this article:

Well, yeah, you're right, it should mean it is sick, but people believe things that fit their version of reality rather than what is actually real. Beauty gives you power, and especially at our age we're more interested in sexual stuff, and appearance, and attractiveness than health. And so younger people take more risks, I've learned in my intro psychology class, and I agree with that.

Through tanning - and the enhancement of appearance that tanning is believed to give - the body assumes seductive power. This seductive power is dependent on the semiotic meanings associated with tanned skin, and we have called this the semiotic seductive power of the human body.

In our interviews we were also interested in learning what channels are influential in the diffusion of messages that reinforce the value of tanning. Without much surprise we learned that most of our interviewees see tanned people on television and in music videos, films, magazines, and advertisements and therefore learn that "tan is in." While it would be a mistake to conclude that every fashionable person tans, one is hard-pressed to pick up a copy of Self or Cosmopolitan or Fitness and find a pasty-looking celebrity. ${ }^{10}$

\section{Health, Risk, and Technology}

In line with existing medical research on the phenomenon of artificial tanning, we found that despite awareness of the risks associated with both natural and artificial tanning, our interviewees were not particularly cautious about their practices (see Coupland and Coupland 1997; Knight, Kirincich, and Farmer 2002). For example, almost no one said they wore goggles under the lamp. Goggles play a critical role in protecting eyes from potential damage, but they also leave unappealing shades of paleness around the eyes. Approximately half of the people in our sample claimed to use some kind of lotion to protect from burns, but many believed that this clashed with their ultimate goal. As Chris put it: "Why would you put protective lotion over your body when you're paying to get tanned?" In fact, there are lotions marketed to artificial tanners. Many of these, despite promising to maintain a tan while protecting skin from burns, seem to have harmful effects on top of the damage caused by lamps (Palmer et al. 2002). While every one of the tanners we interviewed told us they try to tan in moderation (the definition of moderation is highly 
subjective, though), almost everyone experienced a burn at one time or another. Burns ranged from minor annoyances that would abate within a few days to major dermatological problems that required medical attention. In addition to what people told us, two female interviewees were noticeably burned when we spoke to them.

Medical discourse on sunburns, the risk of cancer, and the risk of premature aging seemed to matter little, however. Most of our respondents had collected information about the side effects of tanning from a variety of sources, including salon workers, popular magazine articles, Internet articles, television, and their friends. But just about everyone seemed to downplay this risk. As one young man said: "What can you do these days that does not cause cancer?" Much of this risk-taking behavior was explained to us as a form of "getting the best out of life" and "doing your body a little bad and a little good at the same time." This disposition seems to corroborate our argument about the power of the seduction frame. Tanners are not unaware of an alternative interpretation (the medical frame); they simply prefer to interpret tanning within the seduction frame. In their analysis of medical discourse and sunbathing, Coupland and Coupland (1997) reached a very similar conclusion: health is important, but the appearance of being healthy is more important even if it is detrimental to physical health. This makes especially good sense within the seduction frame: seduction, after all, is a play of appearances and signs, as Baudrillard (1990a) opined.

Few of our informants had direct experience with tanless lotions. Tanless lotions are different from accelerants in that they basically work like a skin dye, allowing one to look tanned without tanning artificially or naturally. While tanless lotions have few side effects, apparently their results are not always satisfactory. Few of our informants had tried tanless lotions, but many of them had a friend or an acquaintance who made regular use of the products and as a result looked "funny" and even "ridiculous" because of their uneven orange or waxy brown tone. We even learned of a young woman who had apparently become "addicted" to tanless lotions and could not leave the house without applying copious doses of her favorite brand.

Besides fostering (and being fostered by) a new relation with our body, artificial tanning evokes the picture of a body increasingly shaped by technological practices. We asked our interviewees to interpret for us the fine line between the real and the artificial through an admittedly complex question.

P.V.: Do you believe that what is natural is beautiful, or do you believe that what is artificial is beautiful?

Katie: Well, both I guess. We always say that what is natural is beautiful, but then we try to re-create whatever is natural through technology. If I said that what is artificial isn't beautiful, after all, I'd contradict myself, you know, why would I tan?

Indeed, this was a difficult issue to investigate, but just about everyone claimed that the line between the natural and the artificial is difficult to draw. In a very pragmatic fashion Katie and others explained to us that they do what makes them feel good, and technology and commerce are driven by this need for the improvement of life. 
Clearly, however, this "need," so typical of the seduction frame, is linked to issues of political economy and material power. If beauty becomes a commodity, then do we not live in a society in which even physical beauty is socially stratified? The answer is yes according to both Bourdieu (1984), who wrote about how physical capital lies at the foundations of a political economy of bodies, and Baudrillard (1968), who explained how desire and consumption are socially stratified. The following reflection by Simone corroborates this argument.

You know, I definitely think so, look how much money goes into looking good, from wearing the right clothes to buying a gym membership, to tanning passes. You need to pay a price to be beautiful in our society. I mean there definitely are people who are poor and are still beautiful, but you just won't see them on TV or at the movies.

Most of the people we interviewed seemed to agree on this point. There was, however, considerable disagreement over the "so what?" element of this scenario. Some reflected on this situation from a position of politically progressive liberalism and condemned the marriage of commercial interests and beauty, whereas others simply told us "this is the way things are." Perhaps biased by our own adherence to feminist ideals, we asked both men and women if this situation is fair at all to women, who are pressured to tan more than men (and engage in related body practices from dieting to wearing makeup). While we encountered a variety of answers, from the more conservative to the more politically emancipatory, we were intrigued with the issue raised by Katja:

OK, I have thought about this one. I consider myself a feminist, a moderate feminist, but a feminist. So why do I do all these things I do to look better? And why do so many women do all these things they do? My take on it is this, if beauty gives us power, then great. I don't know if it is men or women or both that make up all these ideas that we have in our mind, but if a woman gains power over a man in any way, then it's good for women, right? How many guys do you know that go gaga over some girl and will do anything for her? Beauty gives you power.

Here Katja raises critical issues of agency, culture, and the gendered stratification of social structure. While we abstain from tackling ideological reflections on her statement, we come away with the understanding that while social forces shape bodies, bodies also agentically shape these social forces. The issue, therefore, is one of body power as well as of power over bodies, that is, a question of bodies as subject of social action and bodies as objects of social action, and of the blurred boundaries separating these oppositions.

\section{CONCLUSION: SEMIOTIC POWER AND SEDUCTION}

We have argued that the semiotic properties of the medical frame are not as powerful as those of the seduction frame. Meaning possesses semiotic power (Wiley 1994), and the frames through which we interpret the meaning of objects also possess semiotic power. Meaning and interpretive frames derive their semiotic power, at 
least in part, by alluring, charming, and seducing us to believe. Just as we are seduced to believe in the power of the meaning of freedom, justice, and equality, we are equally seduced to believe in the power of the meaning of beauty. Through the seduction frame the tanned self is allured by the semiotic power of tanned beauty. The medical frame is less compelling because it does not hold an equally strong power to seduce the self into belief.

The human body assumes symbolic meaning and also semiotic power through social interaction in a specific context. Through social interaction in the context of postmodern culture - and within the seduction frame in particular-artificial tanners are constantly told that they look "good," "sexy," "beautiful," "young," "healthy," and so forth. Through the mechanism of the looking-glass self (Cooley 1964), these tanners conclude that their appearance is pleasing to others. Because beauty is a valued characteristic in our society, feeling beautiful is directly associated with a more positive self-concept, and such a positive self-concept directly and positively motivates an individual's conduct (Gecas 1991). Therefore, the semiotic seductive power of the tanned body has value for its possessor.

The semiotic seductive power of one's tanned body also has value for others. Not only do people like being looked at, but they also like looking at beautiful, young, healthy, and fit others. This is the idea of scopophilia, more or less explicitly present in the work of Goffman, Baudrillard, and Foucault. The voyeuristic pleasure of the "gaze" is clearly evident in sexual encounters (Waskul 2002) as well as in public and less sexualized encounters (Goffman 1963). The pleasure of the gaze and the frequency and social acceptability of gazing are stronger in a postmodern society where seductive images of the body and of consumer products float abundantly (Featherstone 1991a, 1991b; Glassner 1988, 1989). Perhaps a bit narcissistically, artificial tanners - and arguably many of us in general, whether we tan or not-like to seduce as much as to be seduced. Seduction, as we argued, is a play with meanings and appearances of material objects and of the embodied self.

The self is a sign, as Peirce (1960) believed. In our postmodern culture the self signifies much meaning through changing body images and constantly shifting bodily practices - and thus mostly through surfaces rather than depths. The relation among the body, the self, and society therefore assumes great theoretical importance in postmodern society. But contrary to some of the excesses of postmodern theory, we believe that such a triadic relation is not governed by the illogical play of floating signifiers. The body, much like the self and society, is not just made of fluid meanings but instead is an "empirically verifiable and objectively real thing" (Waskul, Douglass, and Edgley 2000:377). For all its playing with appearances and meaning after all, the tanned self/body is at risk of cancer and death, aging and disease. The importance of a theoretical approach to the body-to-self-to-society (Waskul, Douglass, and Edgley 2000) relationship lies in the need to tease out the relation among dynamics of semiotic reflexivity, historical contingence, individual agency, bodily processes, and matters of sign-value in the context of a political economy of embodied selves and enselfed bodies. 
In this article, we have attempted to specify that the body-to-self-to-society relation is dependent on two closely interrelated forces: the semiotic power of meaning and the power of seduction. We are not alone in suggesting that symbolic interactionists ought to pay more attention to issues of the semiotic power of meaning. Norbert Wiley (1994) and Eugene Rochberg-Halton (1986) reminded us that symbolic interactionists too often neglect the contributions of Charles Sanders Peirce to a semiotic and pragmatic theory of meaning. Peircean ontology holds the key for a reflexive approach to the study of the self and the semiotic power of meaning (Wiley 1994). What is needed is an extension into the terrain of the power of embodied seduction, and we hope this article represents a step in that direction.

\section{NOTES}

1. Our research focuses almost exclusively on Caucasians, or whites, in the United States. While some people of color have also begun to artificially tan their skin in recent years, the more prevalent historical trend has been for people of color to "whiten" or bleach their skin to conform to European-based notions of beauty.

2. We argue that the difference between the symbolic and the semiotic is to be found in the signvalue of an object. In itself bronzed skin is merely an index (Peirce 1960) of a natural phenomenon, sunburn. But in a specific historical, political, economic, and cultural context tanned skin connotes value.

3. Excessive exposure to UV light is also linked to photosensitivity, photo-aging, pseudophorphyria, eye damage, photo-aggravated disease, pruritus, nausea, immunosuppression, polymorphous light eruption, and the formation of basal and squamous skin cell carcinomas and middermal elastolysis. Even the use of most tanning lotions and accelerators is linked to a higher risk of contracting hepatitis and aplastic anemia (see Palmer et al. 2002).

4. Furthermore, while Mead reminded us that though we may produce disparate symbolic meanings out of our bodily action and our embodied interaction, the human body is still anchored in physiological processes that lead to such material events as birth and death. This is not a backward way of reintroducing outdated notions of biological determinism but a way of reminding ourselves that the symbolic and the material are interconnected. The body, as socially constructed as it may be, is still subject to illness, such as skin cancer, and ultimately death (Charmaz 1995; Frank 1991).

5. Seduction is not necessarily a sexual practice. More generally, "seduction" means alluring, charming, and even enticing someone to believe by attraction and charm. Artificial tanners seduce not through sex but through play with meanings. Seductors and seductresses undermine the certainty of meanings through which their tanned bodies are to be interpreted. By doing so, tanned selves lead the objects of their seduction to ask themselves, What is really going on around here? Is this a real fit, healthy, and "naturally" beautiful body? Is this the body of an affluent, ambitious, popular, and successful self?

6. It is important to recognize that the practice of artificial tanning may become more or less fashionable over time. Anecdotal evidence suggests that some may now view tanning as passé and already replaced by the use of tanless lotions or sprays (now offered by a growing number of salons) or even by the permanent alteration of one's skin color, which is becoming increasingly common among both whites and nonwhites. Arguably, this succession of substitutions of simulations with other simulations is indicative of the continuous movement toward the fourth order of simulacra hypothesized by Baudrillard (1983, 1993). Yet, a "retro" return to pale, pasty skin is also feasible. In sum, what is certain is that the presentation of the tanned self assumes meaning and power within the seduction frame, symptomatic of a contemporary society in which power is based on stimulation as much as domination (Baudrillard 1968, 1990a; Foucault 1980). 
7. Prices vary considerably due to the range of collateral services. Some packages, for example, include manicure, pedicure, hair removal, and nail sessions, or even enrollment in fitness classes.

8. Medical frame proponents, however, are quick to claim that a base tan is nothing but a burn on top of which other burns will accumulate (see Spencer and Amonette 1998).

9. This, of course, raises questions related to the social construction of SAD that we cannot pursue here because of space constraints.

10. One young woman pointed out a possible link between larger racial issues and the tanning of Caucasian people. This self-professed fan of rap and hip-hop went as far as to say, "I wish I was black." No other interviewees brought up similar issues, however.

\section{REFERENCES}

American Medical Association (AMA). 1994. House of Delegates Interim Meeting, Resolution 217. Chicago: American Medical Association.

Bancroft, Angus. 1998. "The Model of a Man.” Pp. 26-38 in The Body in Qualitative Research, edited by J. Richardson and A. Shaw. Aldershot: Ashgate.

Baudrillard, Jean. 1968. Le systeme des objects. Paris: Gallimard. 1983. Simulations. New York: Semiotext(e). 1990a. Seduction. New York: St. Martin's Press. 1990b. The Transparency of Evil. London: Verso. 1993. Symbolic Exchange and Death. Thousand Oaks, CA: Sage.

Becker, Howard. 1982. Art Worlds. Berkeley: University of California Press.

Benford, Robert D. and David A. Snow. 2000. "Framing Processes and Social Movements." Annual Review of Sociology 26:611-39.

Blumer, Herbert. 1969. Symbolic Interactionism. Englewood Cliffs, NJ: Prentice Hall.

Bourdieu, Pierre. 1984. Distinction. London: Routledge.

Butler, Judith. 1990. Gender Trouble. New York: Routledge.

Charmaz, Kathy. 1995. “The Body, Identity, and Self.” Sociological Quarterly 36:657-80.

Cokkinides, Vilma, Martin Weinstock, Mary O'Connell, and Michael Thun. 2002. "Use of Indoor Tanning Sunlamps by U.S. Youth, Ages 11-18 Years." Pediatrics 109:1124-30.

Cooley, Charles. 1964. Human Nature and the Social Order. New York: Scribner's.

Corbin, Juliet and Anselm Strauss. 1988. Unending Care and Work. San Francisco: Jossey Bass.

Coupland, Nikolas and Justine Coupland. 1997. "Bodies, Beaches, and Burn-Times: 'Environmentalism' and Its Discursive Competitors." Discourse and Society 8(1):7-25.

Danesi, Marcel. 2003. Forever Young. Toronto: University of Toronto Press.

Demko, Catherine, Elaine Borawski, and Sara Debanne. 2003. "Use of Indoor Tanning Facilities by White Adolescents in the United States." Archives of Pediatrics and Adolescent Medicine 157:854-60.

Denzin, Norman. 1989. The Research Act. Englewood Cliffs, NJ: Prentice Hall. 1992. Symbolic Interactionism and Cultural Studies. Cambridge, MA: Blackwell.

Desmond, Jane. 1999. Staging Tourism. Chicago: University of Chicago Press.

Douglas, Mary. 1966. Purity and Danger. New York: Praeger.

Edgley, Charles and Dennis Brissett. 1990. "Health Nazis and the Cult of the Perfect Body: Some Polemical Observations." Symbolic Interaction 13:257-79.

Falk, Pasi. 1994. The Consuming Body. Thousand Oaks, CA: Sage.

Featherstone, Mike. 1991a. "The Body in Consumer Culture." Pp. 170-96 in The Body, edited by M. Featherstone, M. Hepworth, and B. Turner. Newbury Park, CA: Sage.

.1991b. Consumer Culture and Postmodernism. London: Sage.

Featherstone, Mike, Mike Hepworth, and Bryan Turner, eds. 1991. The Body. Newbury Park, CA: Sage.

Foucault, Michel. 1980. Power/Knowledge. New York: Pantheon. 
Frank, Arthur. 1991. "For a Sociology of the Body." Pp. 36-102 in The Body, edited by M. Featherstone, M. Hepworth, and B. Turner. Newbury Park, CA: Sage.

Gecas, Viktor. 1991. "The Self-Concept as a Basis for a Theory of Motivation." Pp. 171-88 in The Self-Society Dynamic, edited by J. Howard and P. Callero. Cambridge, MA: Cambridge University Press.

Geller, Allan, Graham Colditz, and Susan Oliveria. 2002. "Use of Sunscreen, Sunburning Rates, and Tanning Bed Use among More than 10,000 U.S. Children and Adolescents." Pediatrics 109:1009-14.

Glassner, Barry. 1988. Bodies. New York: Putnam. . 1989. "Fitness and the Postmodern Self." Journal of Health and Social Behavior 30:180-91.

Goffman, Erving. 1959. The Presentation of Self in Everyday Life. New York: Anchor Books. 1963. Behavior in Public Places. New York: Free Press. 1967. Interaction Ritual. Chicago: Aldine.

1969. Strategic Interaction. Philadelphia: University of Pennsylvania Press. 1974. Frame Analysis. New York: Harper and Row.

Gottdiener, Mark. 1985. "Hegemony and Mass Culture." American Journal of Sociology 90:97999. 1995. Postmodern Semiotics. Cambridge, MA: Blackwell.

Grossberg, Lawrence. 1992. We Gotta Get Out of This Place. New York: Routledge.

Halliday, Michael. 1978. Language as Social Semiotics. London: Arnold.

Hodge, Robert and Gunther Kress. 1988. Social Semiotics. Ithaca: Cornell University Press.

Holubar, Karl and C. Schmidt. 1994. Sun and Skin. Vienna: Verlag der Osterreichischen Arztekammer.

Indoor Tanning Association. 2004. "About ITA.” Available at http://www.theita.com/page.php? ArticleID=5. February 4 .

International Agency for Research on Cancer. 1992. Monograph on the Evaluation of Carcinogenic Risks to Humans: Ultraviolet Radiation. Vol. 55. Lyon, France: IARC.

Knight, Matthew, Anna Kirincich, and Evan Farmer. 2002. "Awareness of the Risks of Tanning Lamps Does Not Influence Behavior among College Students." Archives of Dermatology 138:1311-16.

Manning, Peter K. 1987. Semiotics and Fieldwork. Newbury Park, CA: Sage.

Mawn, V. and A. Fleischer. 1993. "A Survey of Attitudes, Beliefs, and Behavior Regarding Tanning Bed Use, Sunbathing, and Sunscreen Use." Journal of the American Academy of Dermatology 29:959-62.

Mead, George Herbert. 1934. Mind, Self and Society. Chicago: University of Chicago Press.

National Institute of Health. 1989. "Sunlight, Ultraviolet Radiation, and the Skin: A National Institute of Health Consensus Development Conference Statement.” Bethesda, MD: U.S. Department of Health and Human Services, Public Health Service 7:1-23.

Netburn, Deborah. 2002. "Young, Carefree and Hooked on Sun Lamps." New York Times, May 26, p. 9.1.

Palmer, Richard, Joni Mayer, Susan Woodruff, Laura Eckhardt, and James Sallis. 2002. "Indoor Tanning Facility Density in Eighty U.S. Cities.” Journal of Community Health 27:191-202.

Peirce, Charles S. 1960. Collected Papers of Charles Sanders Peirce. 6 vols. Cambridge, MA: Harvard University Press.

Randle, Henry. 1997. "Suntanning: Differences in Perceptions throughout History." Mayo Clinic Proceedings 72:461-66.

Richardson, John and Alison Shaw, eds. 1998. The Body in Qualitative Research. Aldershot: Ashgate.

Rochberg-Halton, Eugene. 1986. Meaning and Modernity. Chicago: University of Chicago Press.

Sanders, Clinton. 1989. Customizing the Body. Philadelphia: Temple University Press.

Saussure, Ferdinand de. 1959. Course in General Linguistics. Trans. Wade Baskin. New York: McGraw-Hill.

Shibutani, Tamotsu. 1961. Society and Personality. Berkeley: University of California Press. 
Shilling, Chris. 1993. The Body and Social Theory. London: Sage.

Spencer J. and R. Amonette. 1998. "Tanning Beds and Skin Cancer.” Clinical Dermatology 16:487501.

Stone, Gregory P. 1962. "Appearance and the Self.” Pp. 86-118 in Human Nature and Social Process, edited by A. M. Rose. Boston: Houghton Mifflin.

Strauss, Anselm. 1993. Continual Permutations of Action. New York: Aldine de Gruyter.

Swerdlow, A. J. and M. A. Weinstock. 1998. "Do Tanning Lamps Cause Melanoma? An Epidemiologic Assessment." Journal of the American Academy of Dermatology 38:89-98.

Turner, Bryan. 1991. "Recent Developments in the Theory of the Body." Pp. 1-35 in The Body, edited by M. Featherstone, M. Hepworth, and B. Turner. Newbury Park, CA: Sage. 1996. The Body and Society. 2d ed. Thousand Oaks, CA: Sage.

Vail, Angus. 1999. “Tattoos are like Potato Chips . . Y You Can't Have Just One.” Deviant Behavior 20:253-73.

Vannini, Phillip. 2004. "Toward an Interpretive Analytics of the Sign: Interactionism, Power, and Semiosis." Studies in Symbolic Interaction 26:151-176.

Veblen, Thorstein. 1899. The Theory of the Leisure Class. London: Macmillan.

Waskul, Dennis D. 2002. "The Naked Self.” Symbolic Interaction 25:199-227.

Waskul, Dennis, Mark Douglass, and Charles Edgley. 2000. "Cybersex: Outercourse and the Enselfment of the Body." Symbolic Interaction 23:375-97.

Westerdahl J., C. Ingvar, A. Masback, N. Johnsson, and H. Olsson. 2000. "Risk of Cutaneous Malignant Melanoma in Relation to Use of Sunbeds.” British Journal of Cancer 82:1593-99.

Wiley, Norbert. 1994. The Semiotic Self. Chicago: University of Chicago Press.

Young, Janice Clark and Robert Walker. 1998. "Understanding Students' Indoor Tanning Practices and Beliefs to Reduce Skin Cancer Risks.” American Journal of Health Studies 14:120-27. 